\title{
The effect of climate change and emission scenarios on ozone concentrations over Belgium: a high-resolution model study for policy support
}

\author{
D. Lauwaet ${ }^{1}$, P. Viaene ${ }^{1}$, E. Brisson ${ }^{2}$, N.P.M. van Lipzig ${ }^{2}$, T. van Noije ${ }^{3}$, A. Strunk ${ }^{3}$, S. Van Looy ${ }^{1}$, N. Veldeman ${ }^{1}$, \\ L. Blyth ${ }^{1}$, K. De Ridder ${ }^{1}$, and S. Janssen ${ }^{1}$ \\ ${ }^{1}$ Vlaamse Instelling voor Technologisch Onderzoek (VITO), Boeretang 200, 2400 Mol, Belgium \\ ${ }^{2}$ Physical and Regional Geography Research Group, Department of Earth and Environmental Sciences, K.U. Leuven, \\ Celestijnenlaan 200 E, 3001 Heverlee, Belgium \\ ${ }^{3}$ Royal Netherlands Meteorological Institute (KNMI), P.O. Box 201, 3730 AE De Bilt, the Netherlands
}

Correspondence to: D. Lauwaet (dirk.lauwaet@vito.be)

Received: 19 June 2013 - Published in Atmos. Chem. Phys. Discuss.: 21 January 2014

Revised: 8 May 2014 - Accepted: 9 May 2014 - Published: 16 June 2014

\begin{abstract}
Belgium is one of the areas within Europe experiencing the highest levels of air pollution. A high-resolution $(3 \mathrm{~km})$ modelling experiment is employed to provide guidance to policymakers about expected air quality changes in the near future (2026-2035). The regional air quality model AURORA (Air quality modelling in Urban Regions using an Optimal Resolution Approach), driven by output from a regional climate model, is used to simulate several 10-year time slices to investigate the impact of climatic changes and different emission scenarios on near-surface $\mathrm{O}_{3}$ concentrations, one of the key indices for air quality. Evaluation of the model against measurements from 34 observation stations shows that the AURORA model is capable of reproducing 10-year mean concentrations, daily cycles and spatial patterns. The results for the Representative Concentration Pathways (RCP) 4.5 emission scenario indicate that the mean surface $\mathrm{O}_{3}$ concentrations are expected to increase significantly in the near future due to less $\mathrm{O}_{3}$ titration by reduced $\mathrm{NO}_{\mathrm{x}}$ emissions. Applying an alternative emission scenario for Europe is found to have only a minor impact on the overall concentrations, which are dominated by the background changes. Climate change alone has a much smaller effect on the near-surface $\mathrm{O}_{3}$ concentrations over Belgium than the projected emission changes. The very high horizontal resolution that is used in this study results in much improved spatial correlations and simulated peak concentrations compared to a standard $25 \mathrm{~km}$ simulation. An analysis of the number of
\end{abstract}

peak episodes during summer revealed that the emission reductions in RCP4.5 result in a $25 \%$ decrease of these peak episodes.

\section{Introduction}

Belgium ranks among the areas in Europe with the highest levels of air pollution, failing to meet the targets of the EU Air Quality Directives (EEA, 2012). Air pollution results from a combination of emissions and weather conditions and therefore is sensitive to climate change. As the effects of global climate change are increasingly felt in Belgium, policymakers have expressed interest in quantifying its effect on air pollution and the effort required to meet the air quality targets in the upcoming years and decennia. Therefore the Modelling Atmospheric Composition and Climate for the Belgian Territory (MACCBET) project was initiated.

Within the framework of the project, a modelling experiment is set up in which a regional air quality model is driven by meteorological input from a regional climate model. The study focuses on impacts in the near future (around 2030) since Belgian policymakers, stakeholders in this project, have indicated that this is more relevant than projections to the more distance future (e.g. 2100) as is common practice in scientific literature. The relevance of our results for local policymakers is further increased by applying an additional 
emission scenario that was designed by the Flemish administration.

The choice of this 10-year period around 2030 (20262035) has the advantage that it is not too far in the future, so the emission scenarios can be based on already existing trends and technology, which is not the case for 2100 , and would make the results less concrete for the stakeholders. The disadvantage is that the climate change effect towards 2030 is still limited as the strongest effects are expected towards the end of the century. However, the trends that are visible in 2030 can already teach us a lot about the direction of the climate and air quality evolution in Belgium going forward. The simulated periods in this study are limited to 10 years since we apply a very high horizontal resolution of $3 \mathrm{~km}$, which is needed to capture the high spatial variability of air pollution patterns in Belgium (Lauwaet et al., 2013). This kilometre-scale resolution, unprecedented for this type of study, requires very large computational and data storage capacities and limits the length of the simulations. Still, a 10year period is found to be long enough to derive statistically sound results, especially regarding the mean values (Brisson and van Lipzig, 2012).

The work presented here will focus on near-surface $\mathrm{O}_{3}$ concentrations, one of the key indices for air quality. The future simulations are based on the Intergovernmental Panel on Climate Change (IPCC) Representative Concentration Pathway RCP4.5 (Van Vuuren et al., 2011), one of the RCPs used in the climate simulations of the Coupled Model Intercomparison Project (CMIP5). Studies with global models indicate that RCP4.5 will cause the mean surface $\mathrm{O}_{3}$ concentrations over Europe to decrease slowly over the next century, with only a very slight decrease by 2030 (e.g. Wild et al., 2012; Langer et al., 2012).

The effect of climate and emission changes on $\mathrm{O}_{3}$ concentrations has been the subject of several publications in international literature. Jacob and Winner (2009) reviewed multiple studies on global climate and air quality models and reported that summertime surface $\mathrm{O}_{3}$ concentrations are expected to increase in polluted regions over the coming decades. On the other hand, the higher water vapour level in the future is expected to decrease the background $\mathrm{O}_{3}$ in the troposphere. Similar findings are reported in a recent review paper by Fiore et al. (2012). Also other factors can play a role when looking at the global scale, e.g. changes in the large-scale stratospheric influx of $\mathrm{O}_{3}$ (Kawase et al., 2011; Young et al., 2013). However, in order to obtain results for urban areas and capture spatial distributions, higher resolution regional modelling studies are required.

Over the USA, Lin et al. (2010) and Lam et al. (2011) showed that $\mathrm{O}_{3}$ levels are expected to increase in areas already experiencing high $\mathrm{O}_{3}$ concentrations under the current climate. They also noted that changes to precursor emissions have a larger impact than changes in meteorology associated with climate change. Kelly et al. (2012) also found that climate change alone would lead to increased surface $\mathrm{O}_{3}$ con- centrations, especially in urban areas. However, the effect of emission changes was found to be more dominant and resulted in decreased concentrations, except in very polluted high $\mathrm{NO}_{\mathrm{x}}$ areas where lower precursor concentrations result in less $\mathrm{O}_{3}$ titration and hence higher $\mathrm{O}_{3}$ concentrations.

Also over Europe, several studies with regional chemistry transport models have focused on the effect of climate change on future surface $\mathrm{O}_{3}$ (e.g. Meleux et al., 2007; Katragkou et al., 2011; Langner et al., 2012). Hedegaard et al. (2013) demonstrated that $\mathrm{O}_{3}$ concentration changes are dominated by expected emission reductions, which lead to increases over Benelux, a very polluted area, where less titration will occur. Juda-Rezler et al. (2012) focussed solely on climate change impacts by keeping the anthropogenic emissions constant at year 2000 levels. They found that, under IPCC scenario A1B, the near-surface $\mathrm{O}_{3}$ concentrations would increase up to $10 \%$ over Europe by the end of the 21 st century due to increased summer temperatures and decreased summer precipitation. The mid-century results showed a slight decrease of the concentrations over northern Europe and the Benelux region.

Our work builds on the research mentioned above by applying several emission scenarios and using a horizontal model resolution of $3 \mathrm{~km}$ that is unprecedented for this kind of study. The remainder of this paper is organized as follows. In Sect. 2, both the regional air quality model and the regional climate model, which provides the meteorological input data, are described, as well as all the input data sets and the experiment setups. Section 3 presents the results and discussions of this research while conclusions are drawn in Sect. 4.

\section{Numerical models and experiment setup}

\subsection{The AURORA model}

The simulations in this study are performed with the regional-scale air quality model AURORA (Air quality modelling in Urban Regions using an Optimal Resolution Approach), a limited-area Eulerian chemistry transport model, described in Van de Vel et al. (2009) and Lauwaet et al. (2013) and references therein. The model has been applied and tested in several regional-scale air quality modelling studies (De Ridder et al., 2008; Lefebvre et al., 2011). In the model, the vertical diffusion is calculated with the Crank-Nicholson method (De Ridder and Mensink, 2002), while the horizontal advection uses a Walcek (2000) scheme. The gas phase chemistry is described with the Carbon-Bond V scheme (Yarwood et al., 2005). For dry deposition, AURORA uses the Wesely and Hicks (2000) formalism based on a resistance network. The model needs land use information and the vegetation fraction in a grid cell for determining the canopy resistance. Both the amount and distribution of the vegetation are based on $1 \mathrm{~km}$ SPOT (Système Pour l'Observation de la Terre) vegetation satellite imagery 
(Maisongrande et al., 2004), while the land use type is derived from the $250 \mathrm{~m}$ CORINE (Coordination of Information on the Environment) land use map (European Commission, 1994).

The AURORA model also needs a specification of the position and strength of emission sources. In the AURORA model setup, six emission classes are taken into account, including both gaseous and particle emissions, which are assigned to 26 species using sector specific emission splits. Biogenic emissions are calculated using the Model of Emissions of Gases and Aerosols from Nature (MEGAN, Guenther et al., 2006). The emission data are obtained with the Emission Mapping (Emap) geographical information systems tool (Maes et al., 2009), which provides gridded emissions with a horizontal resolution of $1 \mathrm{~km}$, based on the European Monitoring and Evaluation Programme (EMEP) data set. Based on the official reports by member states, EMEP provides corrected and gap filled expert emissions on a country basis as national totals.

In this emission inventory, sources are broken down over 11 SNAP (Selected Nomenclature for sources of Air Pollution) categories. For each SNAP source category, point source emissions are first allocated on the air quality model domain using the European Pollutant Emissions Register (EPER). Next, remaining non-point emissions are spatially distributed using quantitative spatial surrogate data (e.g. land use, population density and traffic network). Details of the approach can be found in Maes et al. (2009). The resulting annual emissions are distributed temporally according to monthly (January-December), daily (Monday-Sunday) and hourly ( $0-23 \mathrm{~h}$ ) factors, following Builtjes et al. (2003). These factors are specific to each pollutant and emission sector and reflect the different activity patterns as a function of time.

The horizontal grid of AURORA is defined by using a tangent Lambert conformal map projection with an earth radius of $6371 \mathrm{~km}$ and taking the domain centre as true latitude and longitude of the projection. The vertical grid is defined by the terrain following coordinate system of Gal-Chen and Somerville (1975). As this study focuses on the surface level ozone concentrations, the vertical extent of the model domain is limited to $4 \mathrm{~km}$ height, employing 20 model levels with a grid spacing of $25 \mathrm{~m}$ near the surface to $500 \mathrm{~m}$ at the upper boundary. The simulations for this study are performed using one-way grid nesting with two nesting levels (Fig. 1). Figure 2 shows the $3 \mathrm{~km}$ resolution model domain, which covers $101 \times 81$ grid points.

Large-scale pollutant concentrations, which are required to account for remote emission sources, are interpolated from output generated by the chemistry-transport model TM5 (Huijnen et al., 2010) as shown in Fig. 1. TM5 provides 3hourly concentration levels of reactive gases and aerosols. The version applied in this study simulates tropospheric gasphase chemistry as well as aerosol microphysics and uses a horizontal resolution of $3^{\circ} \times 2^{\circ}$ with 34 layers in the vertical.

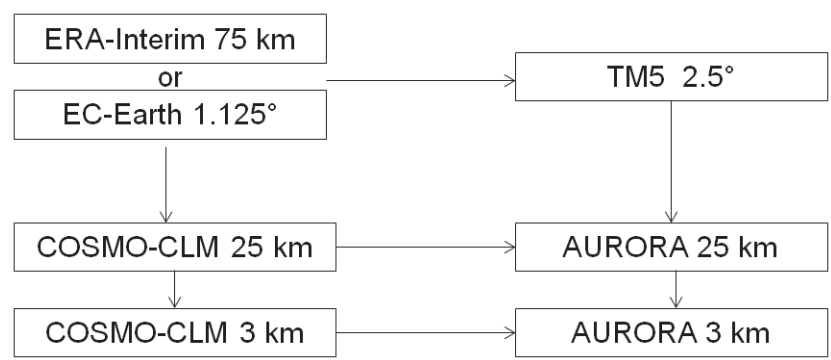

Figure 1. Schematic overview of the coupling between the atmospheric models used in this study and their horizontal resolutions.

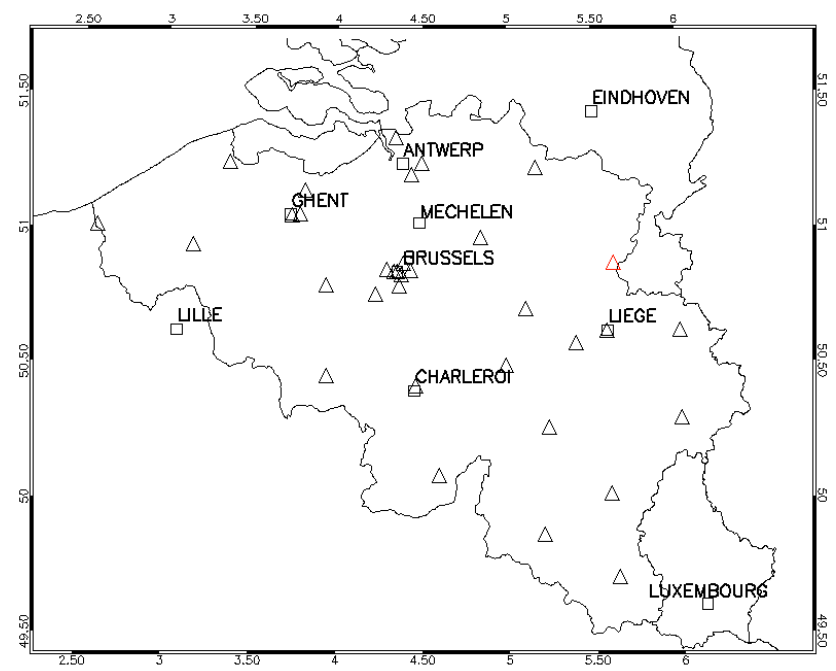

Figure 2. Overview of the $3 \mathrm{~km}$ model domain and the location of major cities (white squares) and observation stations (white triangles). The location of station "Lanaken" is indicated with a red triangle.

Because of the relatively long lifetime of methane $\left(\mathrm{CH}_{4}\right)$, the $\mathrm{CH}_{4}$ concentrations are prescribed at the surface based on observations. $\mathrm{NO}_{\mathrm{x}}$ production by lightning is calculated online, while biogenic and other natural emissions are based on yearly and monthly data sets compiled in the MACC project (Monitoring Atmospheric Composition and Climate) complemented with other data sets described in the paper by Huijnen et al. (2010). The implementation of the emission heights for the different sources and anthropogenic sectors was revised compared to the description given there (van Noije et al., 2014). These emissions are in line with the emissions used in AURORA as both data sets are based on the same total numbers on a country level.

\subsection{The COSMO-CLM model}

The regional climate model COSMO-CLM is the product of a joint effort from the Consortium for Small-scale Modelling (COSMO) and the Climate Limited-area Modelling Community (CLM-Community). These two groups, encompassing 
Table 1. Overview of the applied emission changes from anthropogenic sources and biomass burning between the present day (2000-2009) and the near future (2026-2035).

\begin{tabular}{lrrrr}
\hline Component & $\begin{array}{r}\text { RCP4.5 } \\
\text { Europe }\end{array}$ & $\begin{array}{r}\text { RCP4.5 } \\
\text { Belgium }\end{array}$ & $\begin{array}{r}\text { MIRA } \\
\text { Europe }\end{array}$ & $\begin{array}{r}\text { MIRA } \\
\text { Belgium }\end{array}$ \\
\hline $\mathrm{NO}_{\mathrm{x}}$ & $-60 \%$ & $-70 \%$ & $-45 \%$ & $-25 \%$ \\
$\mathrm{SO}_{\mathrm{x}}$ & $-75 \%$ & $-75 \%$ & $-40 \%$ & $-65 \%$ \\
$\mathrm{NMVOC}$ & $-50 \%$ & $-55 \%$ & $-40 \%$ & $-35 \%$ \\
$\mathrm{PM}$ & $-75 \%$ & $-85 \%$ & $-10 \%$ & $-25 \%$ \\
$\mathrm{NH}_{3}$ & $-6 \%$ & $+15 \%$ & $-30 \%$ & $-25 \%$ \\
\hline
\end{tabular}

national weather services and climate research centres, maintain a common model for both operational weather prediction and regional climate simulations. A detailed description and full documentation of the model is provided by Doms (2011). COSMO-CLM is a non-hydrostatic model that allows applications on a wide range of spatial scales. In this study, we use COSMO-CLM version 4.8. This model version, along with earlier versions, has been extensively evaluated by e.g. Jaeger et al. (2008), Meissner et al. (2009) and Dobler et al. (2011).

Land surface processes are parameterized through the soil module TERRA_ML (Grasselt et al., 2008). The module requires input data sets specifying land surface characteristics, such as land cover, vegetation parameters and soil texture. Soil texture is derived from the Food and Agriculture Organization of the United Nations Digital Soil Map of the World (FAO, 1998). The global land cover map for the year 2000 (GLC2000), developed by the Joint Research Centre of the European Commission (Bartholomé and Belward, 2005), is used to determine vegetation parameters such as leaf area index (LAI) and root depth. Note that this land use map is different from the CORINE map used by AURORA, which might induce small inconsistencies on a local scale. However, TERRA_ML only distinguishes between evergreen forests, deciduous forests and other vegetation, and a comparison with the CORINE data revealed only very minor differences, which are not expected to have a significant effect on the outcome of the simulations.

The COSMO-CLM model uses a rotated spherical coordinate system to define the horizontal model grid, while the vertical grid is defined by a terrain following pressure-based hybrid coordinate system. In all simulations, 40 vertical levels are employed with a grid spacing of $25 \mathrm{~m}$ near the surface, increasing to $1 \mathrm{~km}$ near the upper model boundary, located at $25 \mathrm{~km}$ altitude. The smallest model domain has a horizontal resolution of $3 \mathrm{~km}$ and covers $200 \times 200$ grid points. This large amount of grid cells is needed as the convective parameterization of COSMO-CLM is turned off at this high resolution, and the model needs a large enough domain to develop the resolved convection. The COSMO-CLM simulations are performed using one-way grid nesting, similar to the AURORA simulations (Fig. 1). As the COSMO-CLM and
Table 2. Overview of the applied climate changes between the present day (2000-2009) and the near future (2026-2035) over Belgium per season. The right most column shows the annual mean difference between the ERAINT (based on the ERA-Interim reanalysis) and the Reference scenario. The variables presented here are $2 \mathrm{~m}$ air temperature $\left(T_{2} \mathrm{~m}\right)$, total precipitation amounts (Rain), boundary layer height $(\mathrm{BLH}), 2 \mathrm{~m}$ specific humidity $\left(q_{v}\right)$ and $10 \mathrm{~m}$ wind speed (Wind).

\begin{tabular}{lrrrrr}
\hline Variable & MAM & JJA & SON & DJF & ERAINT \\
\hline$T_{2} \mathrm{~m}$ & $+0.9 \mathrm{~K}$ & $+1.28 \mathrm{~K}$ & $+0.76 \mathrm{~K}$ & $+0.48 \mathrm{~K}$ & $+0.9 \mathrm{~K}$ \\
Rain & $-13 \%$ & $-6 \%$ & $-19 \%$ & $-10 \%$ & $-15 \%$ \\
BLH & $+1 \%$ & $+3 \%$ & $-2 \%$ & $+2 \%$ & $+1 \%$ \\
$q_{v}$ & $+4 \%$ & $+4 \%$ & $+1 \%$ & $+3 \%$ & $+5 \%$ \\
Wind & $-7 \%$ & $-5 \%$ & $-2 \%$ & $+5 \%$ & $-7 \%$ \\
\hline
\end{tabular}

AURORA model grids use a different coordinate system, the COSMO-CLM results are bilinearly interpolated to the AURORA grid points, which adds a small additional uncertainty to the experiments.

\subsection{Experiment setup}

The model chain described above is applied to simulate a 10-year reference period (2000-2009) (REF), driven by meteorological data from the base run of the global climate model EC-Earth (Hazeleger et al., 2010, 2012). Additionally, a 10-year period in the near future (2026-2035) is simulated (RCP4.5), driven by EC-Earth model results for the IPCC Representative Concentration Pathway RCP4.5 (Van Vuuren et al., 2011), one of the RCPs used in CMIP5. Consequently, future emissions from anthropogenic sources and biomass burning in the air quality models are also based on the RCP4.5 data set. To be consistent with the spatial emission patterns of the base run, the country totals are calculated from the RCP4.5 emission map of 2030, and the relative difference with the reference totals is applied to the emission pattern in TM5/AURORA. Similarly, the relative increase in the $\mathrm{CH}_{4}$ concentration in TM5 is prescribed. As a consequence of this approach, eventual land use changes in RCP4.5 that could affect the emission pattern are not taken into account.

To increase the relevance of our results for local policymakers, the 2026-2035 period is also simulated by AURORA with a second emission scenario (called MIRA), that was compiled by the Flemish administration. As this is a local scenario for which only emissions for Europe are considered, only the emissions in the AURORA model domains (both 25 and $3 \mathrm{~km}$ resolution) are changed and the global background from TM5 is the same RCP4.5 scenario as before. An overview of the applied emission and climate change scenarios for the near future is provided in Tables 1 and 2 .

Finally, we want to isolate the climate change effect on surface $\mathrm{O}_{3}$ concentrations over Belgium. Unfortunately, no 

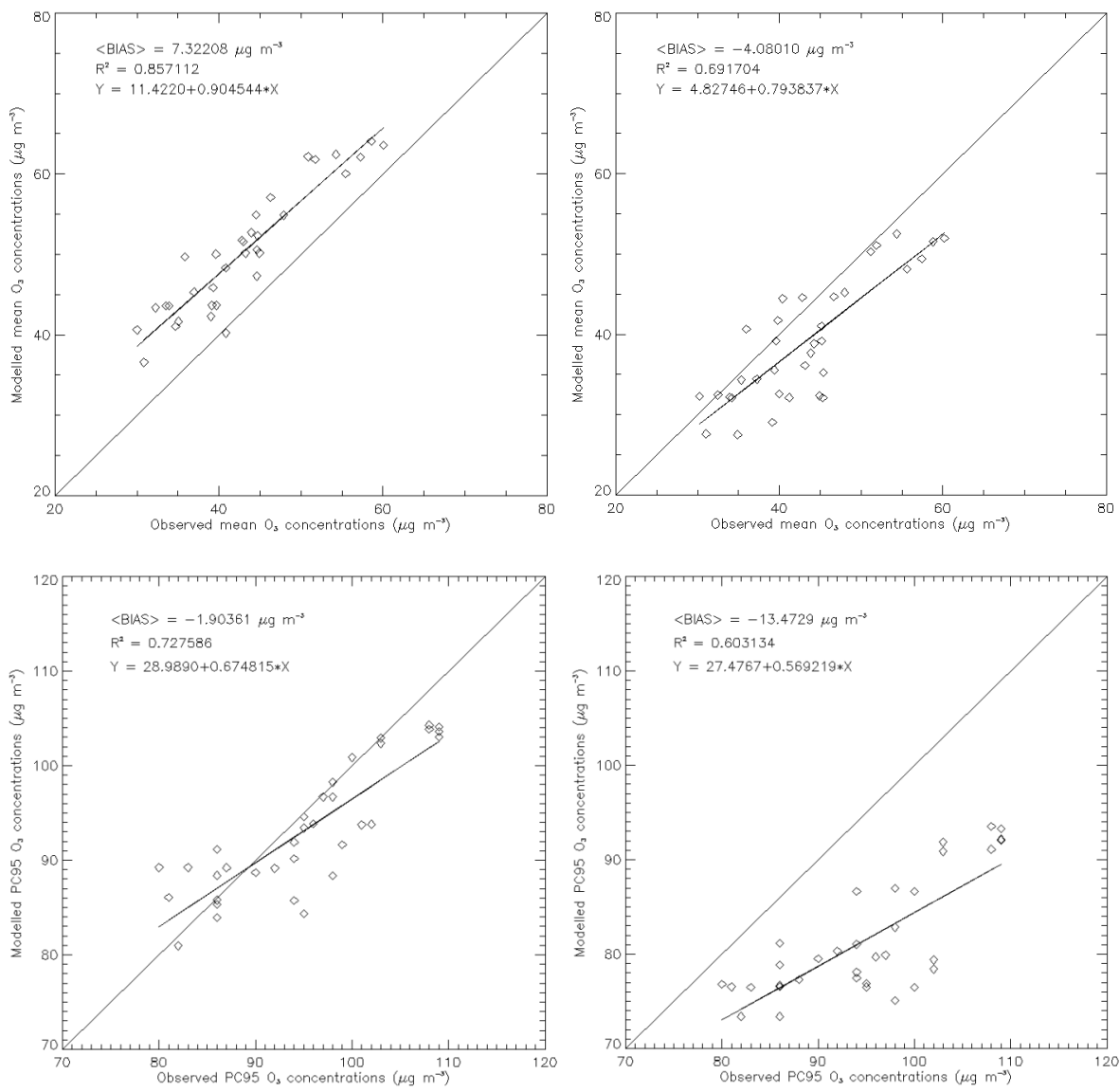

Figure 3. Evaluation of the 10-year (2000-2009) mean and 95th percentile $\mathrm{O}_{3}$ values for all observation stations. Top left: mean $\mathrm{O}_{3}$ concentrations of the $3 \mathrm{~km}$ simulations. Top right: mean $\mathrm{O}_{3}$ concentrations of the $25 \mathrm{~km}$ simulations. Lower left: 95 th percentile $\mathrm{O}_{3}$ values of the $3 \mathrm{~km}$ simulations. Lower right: 95 th percentile $\mathrm{O}_{3}$ values of the $25 \mathrm{~km}$ simulations.

such simulation was planned for the TM5 model in the Modelling Atmospheric Composition and Climate for the Belgian Territory (MACCBET) project. However, another simulation, driven by meteorological fields from the ERA-Interim analysis of the European Centre for Medium-Range Weather Forecasts (ECMWF) for the reference period (2000-2009), provided a valuable alternative (ERAINT). Since the climate change signal from this simulation is very comparable to the RCP4.5 signal (see Table 2), the results of this scenario will give insight into the signal and relative importance of the $\mathrm{O}_{3}$ concentration changes caused by climate change only, relative to the changes caused by the emissions.

\section{Results and discussion}

\subsection{Model performance and added value of the high resolution}

In order to evaluate the model performance, we selected 34 observation stations from the AirBase data archive (Mol et al., 2011). The locations of the stations are shown in Fig. 2 and have a reasonable distribution over the $3 \mathrm{~km}$ model domain. Given this model resolution, we only selected background stations excluding traffic and industrial stations as these are generally not representative for the scale of a $3 \mathrm{~km}$ model grid cell. Since the EC-Earth simulations target a climate realization and not an actual reconstruction of the weather patterns, it is not possible to validate the modelled time series of near-surface $\mathrm{O}_{3}$ concentrations directly by comparison to observations. However, if we remove the yearto-year variability by taking the 10 -year mean values for the present day period, measured and modelled values should be comparable.

Figure 3 demonstrates that the AURORA model with a horizontal resolution of $3 \mathrm{~km}$ is able to reproduce the 10 -year mean observed concentrations with a high spatial coefficient of determination of 0.86 . The model has a slight and fairly constant positive bias at almost all locations. The right-hand side of Fig. 3 shows the evaluation of the $25 \mathrm{~km}$ results for the same observations. Here the spatial correlation is clearly lower (0.69) and the model has a slight negative bias, especially at the locations that are most polluted. The added value 

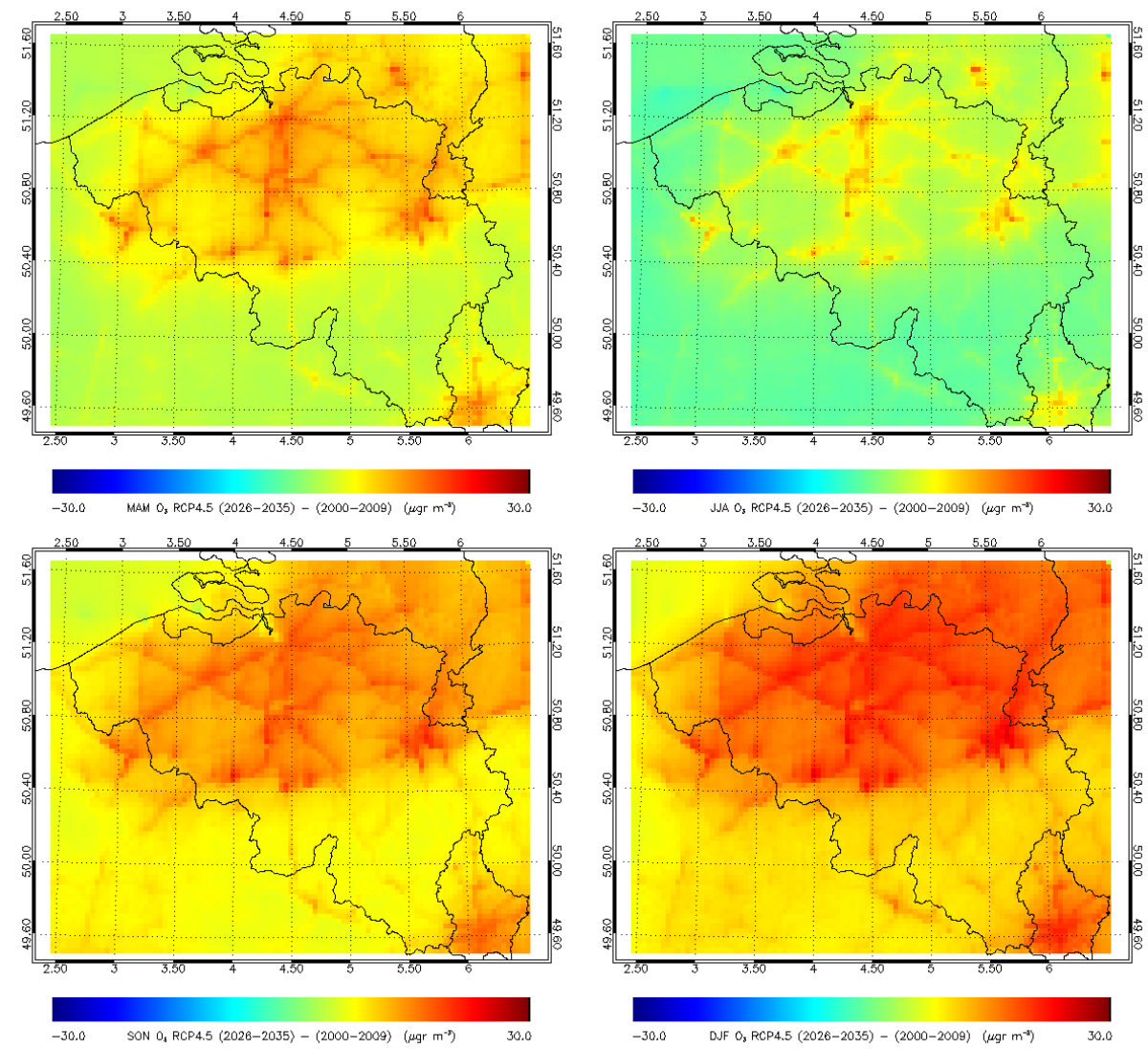

Figure 4. Mean difference maps between the near future (2026-2035) and the present day (2000-2009) for the RCP4.5 scenario per season.

Table 3. Overview of the 10-year mean differences in surface $\mathrm{O}_{3}$ concentrations compared to the Reference scenario over Belgium.

\begin{tabular}{lrrr}
\hline & RCP4.5 & MIRA & ERAINT \\
\hline MAM & $+18 \%$ & $+21 \%$ & $+1 \%$ \\
JJA & $+7 \%$ & $+9 \%$ & $-5 \%$ \\
SON & $+31 \%$ & $+34 \%$ & $-2 \%$ \\
DJF & $+38 \%$ & $+40 \%$ & $-4 \%$ \\
\hline ANNUAL & $+23 \%$ & $+26 \%$ & $-3 \%$ \\
\hline
\end{tabular}

of the high horizontal resolution is further demonstrated in the lower panels of Fig. 3 by evaluating the modelled peak concentrations, taken as the 95th percentile value of the 10year time series. Clearly the $3 \mathrm{~km}$ model results outperform the $25 \mathrm{~km}$ results, which have a strong negative bias and a lower spatial coefficient of determination. From these results we can conclude that the large computational demands that are needed for this high horizontal resolution of $3 \mathrm{~km}$ pay off by significantly improving the spatial correlation and peak concentrations of the simulations.

A further evaluation of the model performance is provided in Sect. 3.2 (Fig. 5), where the mean daily cycle per season is plotted for the observation station "Lanaken" (see Fig. 2).
Clearly the AURORA model captures the shape of the diurnal cycle for all seasons. However, the night time minima are slightly overestimated, which is a common problem in regional air quality models due to difficulties to model the nocturnal boundary layer evolution and its usual stable vertical structure (Juda-Rezler et al., 2012). This prevents the near-surface air from mixing with the air higher up which usually contains higher $\mathrm{O}_{3}$ concentrations. Since the nocturnal mixing is overestimated in these models, so will be the near-surface $\mathrm{O}_{3}$ concentrations.

Overall, the AURORA model performs satisfactorily, the daily cycle is reproduced and the mean spatial pattern for the $\mathrm{O}_{3}$ concentrations is captured.

\subsection{Projection for RCP4.5}

The impact of both climate and emission changes on nearfuture (2026-2035) surface $\mathrm{O}_{3}$ concentrations is shown in Fig. 4 for the different seasons. Overall, the concentrations increase up to $30 \%$ from present day values, especially close to the highways and city centres, the areas with the highest $\mathrm{NO}_{\mathrm{x}}$ emissions. Since these emissions are drastically reduced in the $\mathrm{RCP} 4.5$ scenario, less $\mathrm{O}_{3}$ titration will take place which results in higher concentrations. Clearly the emission changes and their detrimental effect on $\mathrm{O}_{3}$ titration dominate 

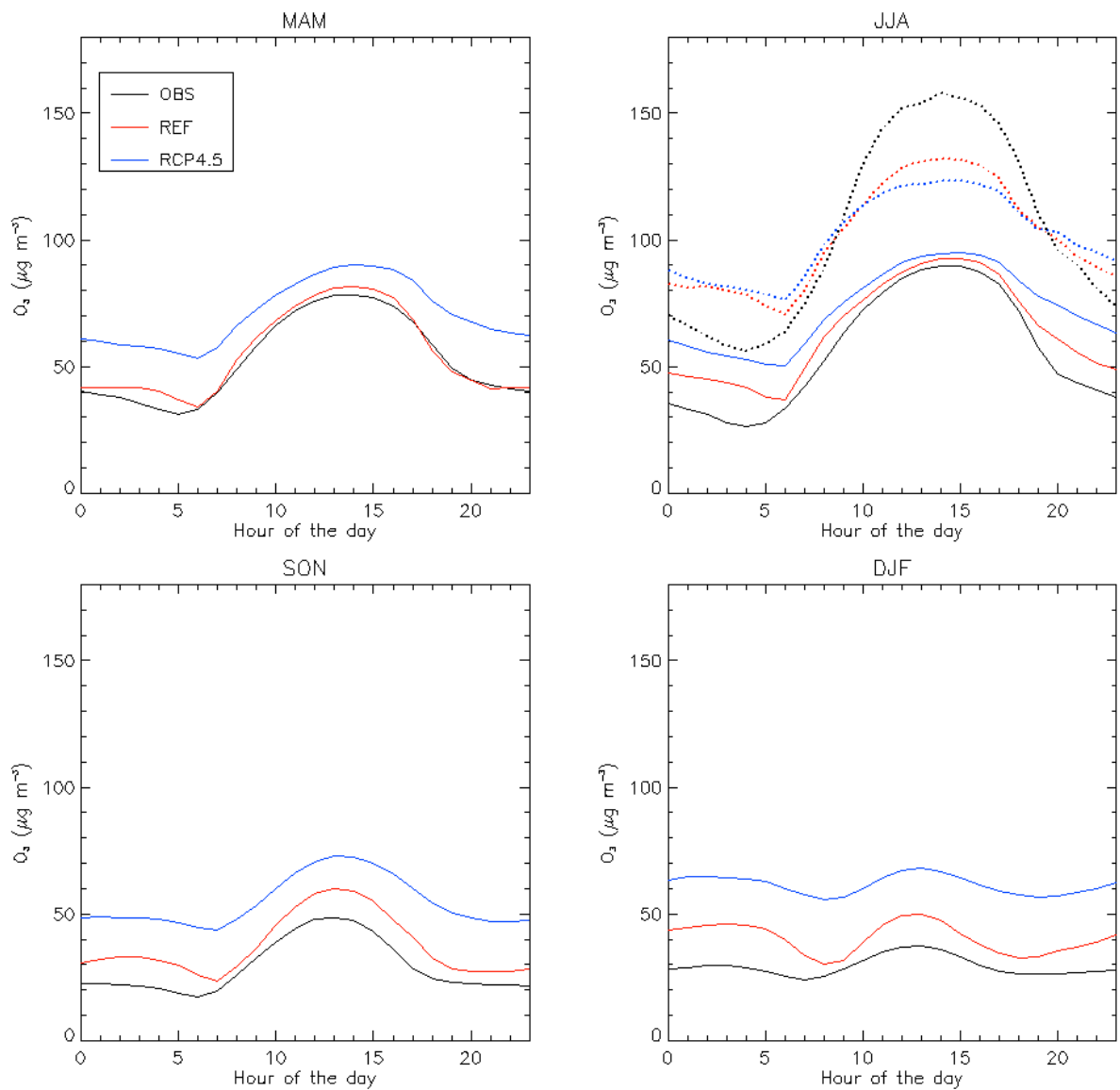

Figure 5. Mean daily cycle of $\mathrm{O}_{3}$ concentrations at station Lanaken per season. In summer, also the 95th percentile is plotted (dotted lines).

the overall image in all seasons. This is in agreement with the findings of Kelly et al. (2012) and Hedegaard et al. (2013) who also noticed an increase in $\mathrm{O}_{3}$ concentrations with decreasing $\mathrm{NO}_{\mathrm{x}}$ emissions in highly polluted areas, such as Belgium.

When looking at the seasonal differences in Fig. 4, it is apparent that the increases are much larger during the winter period (DJF) and much smaller during summer (JJA). The main reason can be found in the global background $\mathrm{O}_{3}$ concentrations, advected into the model domain through the TM5 boundary data. During winter, the background concentrations over Europe in RCP4.5 are higher, primarily due to a reduction of the $\mathrm{O}_{3}$ titration because of the decreased $\mathrm{NO}_{\mathrm{x}}$ emissions. During summer, the background concentrations are lower in RCP4.5 since the increased atmospheric moisture content, due to the temperature increase, accelerates the $\mathrm{O}_{3}$ destruction. Furthermore, the $\mathrm{NO}_{\mathrm{x}}$ emission decrease has a negative effect on $\mathrm{O}_{3}$ concentrations during daytime in summer as it hampers the formation of $\mathrm{O}_{3}$. This global background response to emission reductions is consistent with the multi-model results presented by Fiore et al. (2009), who found that a reduction of the $\mathrm{NO}_{\mathrm{x}}$ emissions in Europe by
$20 \%$ leads to an increase of the mean $\mathrm{O}_{3}$ concentration in Europe in winter and a decrease in summer.

Furthermore, local processes also play a role in explaining the seasonal differences: the boundary layer is much lower during winter, which prevents the mixing of the $\mathrm{NO}_{\mathrm{x}}$ emissions and increases the efficiency of the titration process. Also, the reduction of non-methane volatile organic compound (NMVOC) emissions in RCP4.5 (see Table 1) affects the $\mathrm{O}_{3}$ formation during summer and is an additional reason for the lower response in this season. This effect is much smaller during winter since the absolute values of NMVOC emissions are much lower then.

However, the overall picture of Fig. 4 obscures some interesting underlying trends. Figure 5 shows a detailed analysis that is performed for the station Lanaken (see Fig. 2) and where the mean daily cycles are plotted per season. The results show that the $\mathrm{O}_{3}$ increases are largest at nighttime and during the winter period, when the titration effect plays its role. During daytime in summer, the overall increase is very small. When we consider the peak episodes (plotted as the 95th percentile), we even see a decrease in the concentrations as the reduced NMVOC and $\mathrm{NO}_{\mathrm{x}}$ emissions limit the $\mathrm{O}_{3}$ formation during these episodes. This is 

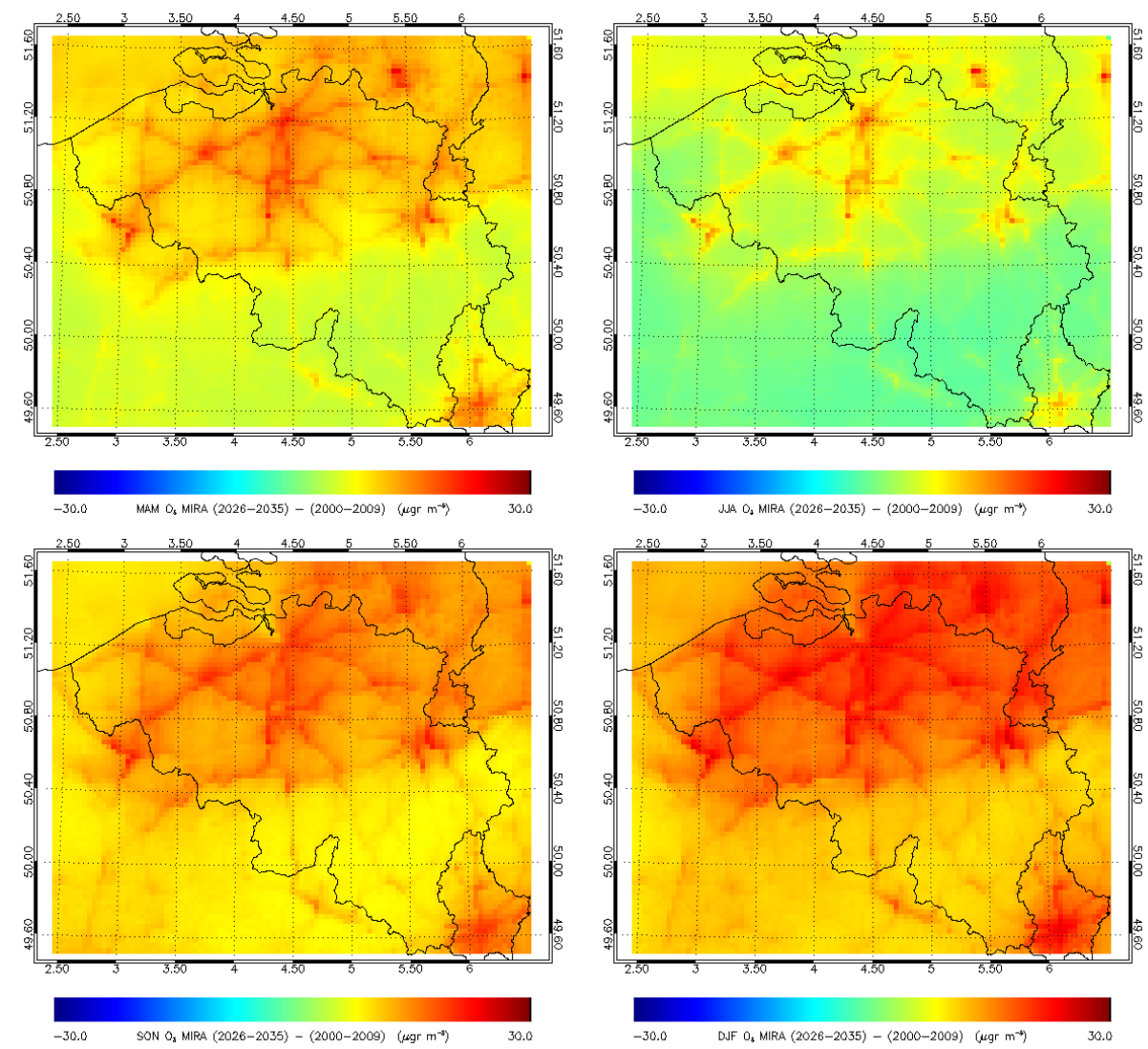

Figure 6. Mean difference maps between the near future (2026-2035) and the present day (2000-2009) for the MIRA scenario per season.

also apparent in the number of days where the $8 \mathrm{~h}$ maximum threshold of $120 \mathrm{~g} \mathrm{~m}^{-3}$ is exceeded: these are reduced by $25 \%$. Thus, although the overall numbers show a significant increase in surface $\mathrm{O}_{3}$ concentrations, the emission reductions are able to suppress the number of exceedances of the threshold value.

\subsection{Effect of a local emission scenario}

The 2026-2035 period is also simulated with an alternative local emission scenario, drafted by the Flemish administration. This scenario envisions less drastic reductions of the emissions (Table 1). The impact on near-future $\mathrm{O}_{3}$ concentrations, presented in Fig. 6, is comparable to Fig. 4. Clearly the results look very similar to the RCP4.5 results, although the differences in the local emission changes are significant. Again the reduction of the $\mathrm{O}_{3}$ titration close to highways and city centres dominates the overall image, while the increases are larger during winter and less pronounced during summer due to the reasons explained in Sect. 3.2.

A quantification of the differences is provided in Table 3. The increase of $\mathrm{O}_{3}$ concentrations is slightly higher for this scenario than for RCP4.5 which means that the additional reduction of NMVOC and $\mathrm{NO}_{\mathrm{x}}$ emissions in RCP4.5 affects the $\mathrm{O}_{3}$ formation more than it affects the $\mathrm{O}_{3}$ titration. Hence when applying these large emission reductions, the results changed from an increase in $\mathrm{O}_{3}$ concentrations since the titration effect is more important than the reduced production (high $\mathrm{NO}_{\mathrm{x}}$ regime) to a decrease of $\mathrm{O}_{3}$ concentrations since reduced production is dominant over the titration effect (low $\mathrm{NO}_{\mathrm{x}}$ regime).

Generally, from these results it can be concluded that the local emission changes, although they are significant, have little impact on the domain-wide $\mathrm{O}_{3}$ concentrations with constant (global) background concentrations.

\subsection{Effect of climate change}

The results of the simulations presented above included the effect of changes in both the emissions and the climate. To assess the relative importance of a comparable climate change impact alone, the ERAINT experiment is used, which includes similar changes in the climate variables as the RCP4.5 scenario when compared to the reference scenario. This is shown in Table 2, where the 10-year mean values are compared, and in Fig. 7, which shows the histograms of the hourly area-mean $2 \mathrm{~m}$ temperatures and rainfall amounts for all scenarios. ERAINT and RCP4.5 have a similar shift towards higher temperatures and fewer small rainfall events compared to the reference scenario. Clearly the climate 

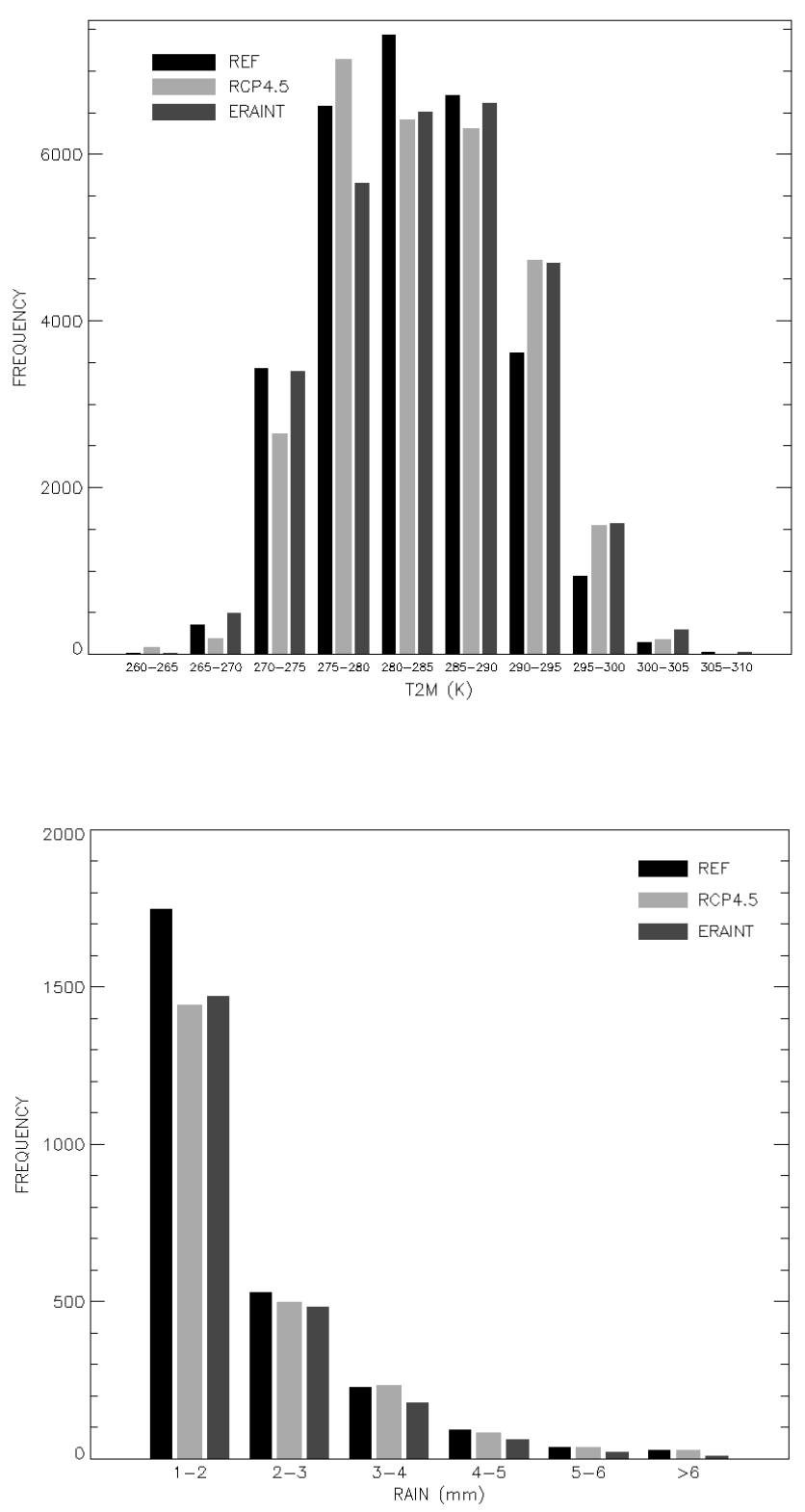

Figure 7. Histogram of hourly mean $2 \mathrm{~m}$ air temperatures (top panel) and rainfall amounts (lower panel) for all scenarios.

change signal is not identical (e.g. there are slightly fewer heavy rainfall events in ERAINT), but both scenarios seem comparable enough to obtain our objective to get an estimate of the relative importance of the climate change effect alone.

Figure 8 shows the 10-year mean results of this simulation. Overall, the changes in the $\mathrm{O}_{3}$ concentrations are much smaller than in the previous experiments, as can also be seen in Table 3; the difference being almost a factor of 10. This is in agreement with the results of Kelly et al. (2012) and Hedegaard et al. (2013): the $\mathrm{O}_{3}$ concentration changes are dominated by the expected emission reductions over the expected climatic changes.

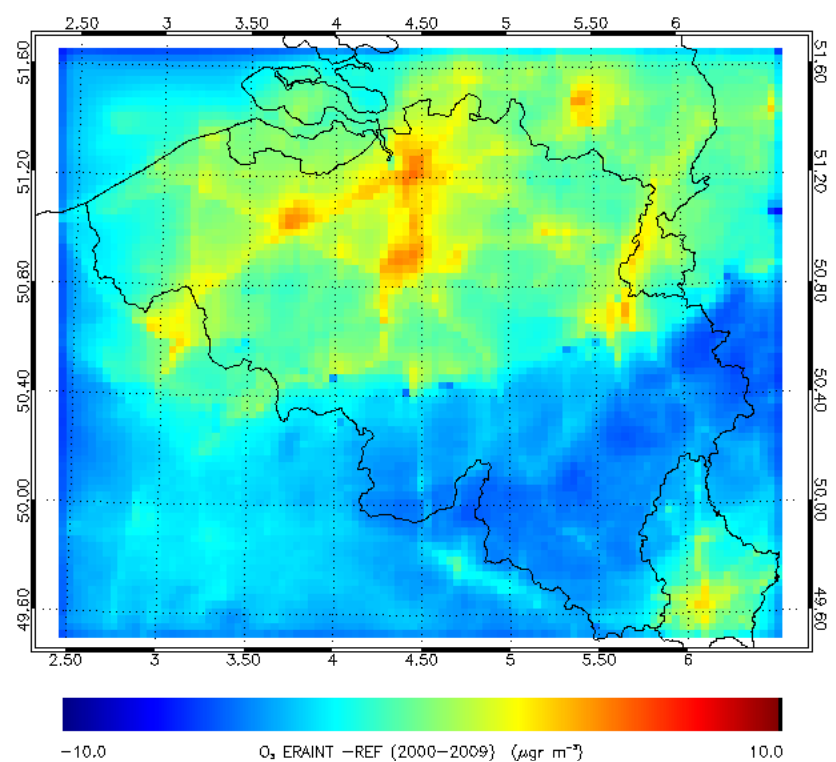

Figure 8. Mean difference map between the ERAINT and the Reference scenario for the present day (2000-2009).

Over Belgium, the climate change effect for 2030 in our set-up causes a slight decrease of the domain-wide surface $\mathrm{O}_{3}$ concentrations. This negative effect is the result of a decrease in the background concentrations from TM5 due to the higher water vapour (caused by higher temperatures) in the troposphere which enhances the destruction of $\mathrm{O}_{3}$. There is also a notable increase in the influx of $\mathrm{O}_{3}$ from the stratosphere, but this causes only minor changes in surface concentrations over the period considered. However, over the polluted areas (e.g. Antwerp, Brussels, Ghent) the concentrations increase because of enhanced $\mathrm{O}_{3}$ production under the drier and warmer conditions. This corresponds to the findings of Jacob and Winner (2009) that the background concentrations will decrease while the surface $\mathrm{O}_{3}$ in polluted regions will increase due to climate change. Using a different IPCC scenario, Juda-Rezler et al. (2012) also found a slight decrease of the surface $\mathrm{O}_{3}$ concentrations over the Benelux region by the middle of the 21 st century, before going towards overall increases by the end of the century.

\section{Conclusions}

In this paper, the effect of climate change and two different emission scenarios on near-future (2026-2035) surface $\mathrm{O}_{3}$ concentrations over Belgium was investigated with the regional air quality model AURORA at an unprecedented horizontal resolution of $3 \mathrm{~km}$. For the experiments considered here, AURORA was driven by meteorological input from the regional climate model COSMO-CLM using the same nesting strategy. Large-scale boundary conditions for meteorology and pollutant concentrations were obtained from the 
global climate model EC-Earth or the ERA-Interim reanalysis of ECMWF and the global chemistry transport model TM5 respectively.

The model was able to reproduce the spatial patterns and 10 -year mean values at 34 observation stations accurately, with a small positive bias and a spatial coefficient of determination of 0.86 . The results for the near future showed that the surface $\mathrm{O}_{3}$ concentrations are expected to increase significantly over Belgium, due to less $\mathrm{O}_{3}$ titration by lower $\mathrm{NO}_{\mathrm{x}}$ emissions, in accordance with the results of related international studies. The increase was found to be larger during winter than during summer, caused by alterations of the (global) background $\mathrm{O}_{3}$ concentrations and local effects (e.g. reduced NMVOC emissions).

Applying an alternative local emission scenario with less drastic emission reductions was found to have little impact on the outcome of the simulations. The domain-wide $\mathrm{O}_{3}$ concentrations for a region such as Belgium seem to be dominated by the background concentrations. When investigating the effects of the applied climate change alone, the impact on the $\mathrm{O}_{3}$ concentrations was much smaller than the combined effect of emission and climate changes (Table 3 ). The climate changes (higher temperatures and less precipitation) resulted in slightly lower concentrations, due to changes in the background concentrations. However, in the most polluted regions the warmer and drier conditions increased the $\mathrm{O}_{3}$ production. This confirms the findings of several other regional modelling studies that future $\mathrm{O}_{3}$ concentration changes are dominated by projected emission changes rather than climatic changes.

The added value of the paper is mainly in the very high horizontal resolution of the simulations. This required substantial computing and data storage facilities, but resulted in much better validation statistics compared to the $25 \mathrm{~km}$ simulations, a commonly used resolution. Especially the peak $\mathrm{O}_{3}$ concentrations, taken as the 95 th percentile values, were significantly improved by using the $3 \mathrm{~km}$ resolution. The good model performance regarding the peak concentrations did build confidence for a further seasonal analysis, which revealed that the emission reductions in RCP4.5 pay off during peak episodes in summer so that the number of days exceeding the $8 \mathrm{~h}$ maximum threshold of $120 \mu \mathrm{g} \mathrm{m}^{-3}$ was reduced by $25 \%$ over Belgium.

Acknowledgements. This research has been performed in the framework of the Climate and Air Quality Modelling for Policy Support (CLIMAQS) project, sponsored by the Flemish agency for Innovation by Science and Technology, and the Modelling Atmospheric Composition and Climate for the Belgian Territory (MACCBET) project, funded by the Science for a Sustainable Development (SSD) program of the Belgian Science Policy Office (BELSPO) under contract number SD/CS/04A.

Edited by: S. Galmarini

\section{References}

Bartholomé, E. and Belward, A. S.: GLC2000: a new approach to global land cover mapping from Earth observation data, Int. J. Remote Sens., 26, 1959-1977, 2005.

Brisson, E. and van Lipzig, N.: How does natural climate variability on decadal timescales affect timeseries analysis?, Geophys. Res. Abstracts, Vol. 14, EGU2012-13559, 2012.

Builtjes, P. J. H., van Loon, M., Schaap, M., Teeuwisse, S., Visschedijk, A. J. H., and Bloos, J. P.: Project on the modelling and verification of ozone reduction strategies: contribution of TNOMEP, TNO-report, MEP-R2003/166, Apeldoorn, the Netherlands, 2003.

De Ridder, K. and Mensink, C.: Improved algorithms for advection and vertical diffusion in AURORA, in: Air pollution modeling and its application XV, edited by: Borrego C. and Schayes G., 395-401. New York: Kluwer, 2002.

De Ridder, K., Lefebre, F., Adriaensen, S., Arnold, U., Beckroege, W., Bronner, C., Damsgaard, O., Dostal, I., Dufek, J., Hirsch, J., Int Panis, L., Kotek, Z., Ramadier, T., Thierry, A., Vermoote, S., Wania, A., and Weber, C.: Simulating the impact of urban sprawl on air quality and population exposure in the German Ruhr area. Part II: Development and evaluation of an urban growth scenario, Atmos. Environ., 42, 7070-7077, 2008.

Dobler, A. and Ahrens, B.: Four climate change scenarios for the Indian summer monsoon by the regional climate model COSMO-CLM, J. Geophys. Res., 116, D24104, doi:10.1029/2011JD016329, 2011.

Doms, G.: A description of the nonhydrostatic regional COSMOmodel. Part 1: dynamics and numerics. Consortium for SmallScale Modelling, Deutscher Wetterdienst, Offenbach, Germany, 2011.

European Commission: CORINE Land Cover Technical Guide, EUR 12585 EN, OPOCE Luxembourg, 1994.

European Environment Agency: Air quality in Europe 2012 report, EEA report 04/2012, Copenhagen (Denmark), doi:10.2800/55823, 2012.

Fiore, A. M., Dentener, F. J., Wild, O., Cuvelier, C., Schultz, M. G., Hess, P., Textor, C., Schulz, M., Doherty, R. M., Horowitz, L.W., MacKenzie, I. A., Sanderson, M. G., Shindell, D. T., Stevenson, D. S., Szopa, S., van Dingenen, R., Zeng, G., Atherton, C.S., Bergmann, D. J., Bey, I., Carmichael, G. R., Collins, W. J., Duncan, B. N., Faluvegi, G., Folberth, G. A., Gauss, M., Gong, S., Hauglustaine, D., Holloway, T., Isaksen, I. S. A., Jacob, D. J., Jonson, J. E., Kaminski, J. W., Keating, T. J., Lupu, A., Marmer, E., Montanaro, V., Park, R. J., Pitari, G., Pringle, K. J., Pyle, J.A., Schroeder, S., Vivanco, M. G., Wind, P., Wojcik, G., Wu, S., and Zuber, A.: Multimodel estimates of intercontinental sourcereceptor relationships for ozone pollution, J. Geophys. Res., 114, D04301, doi:10.1029/2008JD010816, 2009.

Fiore, A. M., Naik, V., Spracklen, D. V., Steiner, A., Unger, N., Prather, M., Bergmann, D., Cameron-Smith, P. J., Cionni, I., Collins, W. J., Dalsoren, S., Eyring, V., Folberth, G. A., Ginoux, P., Horowitz, L. W., Josse, B., Lamarque, J. F., MacKenzie, I. A., Nagashima, T., O’Connor, F. M., Righi, M., Rumbold, S. T., Shindell, D. T., Skeie, R. B., Sudo, K., Szopa, S., Takemura, T., and Zeng, G.: Global air quality and climate, Chem. Soc. Rev., 41, 6663-6683, doi:10.1039/c2cs35095e, 2012.

Food and Agriculture Organization of the United Nations (FAO): Digital Soil Map of the World and Derived Soil Properties CD- 
ROM. FAO, Land and Water Digital Media Series Number1, ISBN 92-5-104050-8, Rome, Italy, 1998.

Gal-Chen, T. and Somerville, C. J.: On the use of a coordinate transformation for the solution of the Navier-Stokes aquations, J. Comp. Phys., 17, 209-228, 1975.

Grasselt, R., Schuettemeyer, D., Warrach-Sagi, K., Ament, F., and Simmer, C.: Validation of TERRA-ML with discharge measurements, Meteorol. Z., 17, 763-773, 2008.

Guenther, A., Karl, T., Harley, P., Wiedinmyer, C., Palmer, P. I., and Geron, C.: Estimates of global terrestrial isoprene emissions using MEGAN (Model of Emissions of Gases and Aerosols from Nature), Atmos. Chem. Phys., 6, 3181-3210, doi:10.5194/acp-63181-2006, 2006.

Hazeleger, W., Severijns, C., Semmler, T., Stefanescu, S., Yang, S., Wang, X., Wyser, K., Dutra, E., Baldasano, J. M., Bintanja, R., Bougeault, P., Caballero, R., Ekman, A. M. L., Christensen, J. H., van den Hurk, B., Jiminez, P., Jones, C., Kållberg, P., Koenigk, T., McGrath, R., Miranda, P., Van Noije, T., Palmer, T., Parodi, J. A., Schmith, T., Selten, F., Storelymo, T., Sterl, A., Tapamo, H., Vancoppenolle M., Viterbo, P., and Willén, U.: EC-Earth: A Seamless Earth System Prediction Approach in Action, B. Am. Meteorol. Soc., 91, 1357-1363, doi:10.1175/2010BAMS2877.1, 2010.

Hazeleger, W., Wang, X., Severijns, C., Stefanescu, S., Bintanja, R., Sterl, A., Wyser, K., Semmler, T., Yang, S., van den Hurk, B., van Noije, T., van der Linden, E., and van der Wiel, K.: EC-Earth V2.2: description and validation of a new seamless earth system prediction model, Clim. Dynam., 39, 2611-2629, 2012.

Hedegaard, G. B., Christensen, J. H., and Brandt, J.: The relative importance of impacts from climate change vs. emissions change on air pollution levels in the 21st century, Atmos. Chem. Phys., 13, 3569-3585, doi:10.5194/acp-13-3569-2013, 2013.

Huijnen, V., Williams, J., van Weele, M., van Noije, T., Krol, M., Dentener, F., Segers, A., Houweling, S., Peters, W., de Laat, J., Boersma, F., Bergamaschi, P., van Velthoven, P., Le Sager, P., Eskes, H., Alkemade, F., Scheele, R., Nédélec, P., and Pätz, H.-W.: The global chemistry transport model TM5: description and evaluation of the tropospheric chemistry version 3.0, Geosci. Model Dev., 3, 445-473, doi:10.5194/gmd-3-445-2010, 2010.

Jacob, D. J. and Winner, D. A.: Effect of climate change on air quality, Atmos. Environ., 43, 51-63, 2009.

Jaeger, E. B., Anders, I., Luethi, D., Rockel, B., Schaer, C., and Seneviratne, S. I.: Analysis of ERA40-driven CLM simulations for Europe, Meteorol. Z., 17, 349-367, 2008.

Juda-Rezler, K., Reizer, M., Huszar, P., Krüger, B. C., Zanis, P., Syrakov, D., Katragkou, E., Trapp, W., Melas, D., Chervenkov, H., Tegoulias, I., and Halenka, T.: Modelling the effects of climate change on air quality over Central and Eastern Europe: concept, evaluation and projections, Climate Res., 53, 179-203, 2012.

Katragkou, E., Zanis, P., Kioutsioukis, I., Tegoulias, I., Melas, D., Krüger, B. C., and Coppola, E.: Future climate change impacts on summer surface ozone from regional climate-air quality simulations over Europe, J. Geophys. Res., 116, D22307, doi:10.1029/2011JD015899, 2011.

Kawase, H., Nagashima, T., Sudo, K., and Nozawa, T.: Future changes in tropospheric ozone under Representative Concentration Pathways (RCPs), Geophys. Res. Lett., 38, L05801, doi:10.1029/2010GL046402, 2011.
Kelly, J., Makar, P. A., and Plummer, D. A.: Projections of mid-century summer air-quality for North America: effects of changes in climate and precursor emissions, Atmos. Chem. Phys., 12, 5367-5390, doi:10.5194/acp-12-5367-2012, 2012.

Lam, Y. F., Fu, J. S., Wu, S., and Mickley, L. J.: Impacts of future climate change and effects of biogenic emissions on surface ozone and particulate matter concentrations in the United States, Atmos. Chem. Phys., 11, 4789-4806, doi:10.5194/acp-11-47892011, 2011.

Langner, J., Engardt, M., and Andersson, C.: European summer surface ozone 1990-2100, Atmos. Chem. Phys., 12, 10097-10105, doi:10.5194/acp-12-10097-2012, 2012.

Lauwaet, D., Viaene, P, Brisson, E., van Noije, T., Strunk, A., Van Looy, S., Maiheu, B., Veldeman, N., Blyth, L., De Ridder, K., and Janssen, S.: Impact of nesting resolution jump on dynamical downscaling ozone concentrations over Belgium, Atmos. Environ., 67, 46-52, 2013.

Lefebvre, W., Vercauteren, J., Schrooten, L., Janssen, S., Degrauwe, B., Maenhaut, W., de Vlieger, I., Vankerkom, J., Cosemans, G., Mensink, C., Veldeman, N., Deutsch, F., Van Looy, S., Peelaerts, W., and Lefebre, F.: Validation of the MIMOSA-AURORAIFDM model chain for policy support: Modeling concentrations of elemental carbon in Flanders, Atmos. Environ., 45, 67056713, 2011.

Lin, J.-T., Wuebbles, D. J., Huang, H.-C., Tao, Z., Caughhey, M., Liang, X.-Z., Zhu, J.-H., and Holloway, T.: Potential effects of climate and emission changes on surface ozone in the Chicago area, Journal of Great Lakes Research, 36 (Supplement 2), 5964, 2010.

Maes, J., Vliegen, J., Van de Vel, K., Janssen, S., Deutsch, F., De Ridder, K., and Mensink, C.: Spatial surrogates for the disaggregation of CORINAIR emission inventories, Atmos. Environ., 43, 1246-1254, 2009.

Maisongrande, P., Duchemin, B., and Dedieu, G.: VEGETATION/SPOT: an operational mission for Earth monitoring: Presentation of new standard products, Int. J. Remote Sens., 25, 914, 2004.

Meissner, C., Schädler, G., Panitz, H.-G., Feldmann, H., and Kottmeier, C.: High-resolution sensitivity studies with the regional climate model COSMO-CLM, Meteorol. Z., 18, 543-557, 2009.

Meleux, F., Solmon, F., and Giorgi, F.: Increase in summer European ozone amounts due to climate change, Atmos. Environ., 41, 7577-7587, doi:10.1016/j.atmosenv.2007.05.048, 2007.

Mol, W. J. A., van Hooydonk, P. R., and de Leeuw, F. A. A. M.: The state of the air quality in 2009 and the European exchange of monitoring information in 2010, ETC/ATM Technical paper 2011/1, European Topic Centre of Air Pollution and Climate Change Mitigation, Bilthoven, the Netherlands, 2011.

Van de Vel, K., Mensink, C., De Ridder, K., Deutsch, F., Maes, J., Vliegen, J., Aloyan, A., Yermakov, A., Arutyunyan, V., Khodzher, T., and Mijling, B.: Air-quality modelling in the Lake Baikal region, Environ. Monit. Assess., 165, 665-674, 2009.

van Noije, T. P. C., Le Sager, P., Segers, A. J., van Velthoven, P. F. J., Krol, M. C., and Hazeleger, W.: Simulation of tropospheric chemistry and aerosols with the climate model EC-Earth, Geosci. Model Dev. Discuss., 7, 1933-2006, doi:10.5194/gmdd-7-19332014, 2014. 
Van Vuuren, D. P., Edmonds, J., Kainuma, M., Riahi, K., Thomson, A., Hibbard, K., Hurtt, G. C., Kram, T., Krey, V., Lamarque, J.F., Masui, T., Meinshausen, M., Nakicenovic, N., Smith, S. J., and Rose, S. K.: The representative concentration pathways: an overview, Climatic Change, 109, 5-31, 2011.

Walcek, C. J.: Minor flux adjustment near mixing ratio extremes for simplified yet highly accurate monotonic calculation of tracer advection, J. Geophys. Res., 105, 9335-9348, 2000.

Wesely, M. L. and Hicks, B. B.: A review of the current status of knowledge on dry deposition, Atmos. Environ., 34, 2261-2282, 2000.

Wild, O., Fiore, A. M., Shindell, D. T., Doherty, R. M., Collins, W. J., Dentener, F. J., Schultz, M. G., Gong, S., MacKenzie, I. A., Zeng, G., Hess, P., Duncan, B. N., Bergmann, D. J., Szopa, S., Jonson, J. E., Keating, T. J., and Zuber, A.: Modelling future changes in surface ozone: a parameterized approach, Atmos. Chem. Phys., 12, 2037-2054, doi:10.5194/acp-12-20372012, 2012.
Yarwood, G., Rao, S., Yocke, M., and Whitten, G. Z.: Updates to the Carbon Bond chemical mechanism: CB05. Final Report to the US EPA, RT-0400675,8 December 2005, online available at: http://www.camx.com/publ/pdfs/cb05_final_ report_120805.pdf, last access: 8 December 2005.

Young, P. J., Archibald, A. T., Bowman, K. W., Lamarque, J.-F., Naik, V., Stevenson, D. S., Tilmes, S., Voulgarakis, A., Wild, O., Bergmann, D., Cameron-Smith, P., Cionni, I., Collins, W. J., Dalsøren, S. B., Doherty, R. M., Eyring, V., Faluvegi, G., Horowitz, L. W., Josse, B., Lee, Y. H., MacKenzie, I. A., Nagashima, T., Plummer, D. A., Righi, M., Rumbold, S. T., Skeie, R. B., Shindell, D. T., Strode, S. A., Sudo, K., Szopa, S., and Zeng, G.: Preindustrial to end 21 st century projections of tropospheric ozone from the Atmospheric Chemistry and Climate Model Intercomparison Project (ACCMIP), Atmos. Chem. Phys., 13, 20632090, doi:10.5194/acp-13-2063-2013, 2013. 